\title{
Farm Fairs and Petting Zoos: A Review of Animal Contact as a Source of Zoonotic Enteric Disease
}

\author{
Cheyenne C. Conrad, ${ }^{1-3}$ Kim Stanford, ${ }^{2}$ Claudia Narvaez-Bravo,, Todd Callaway, and Tim McAllister ${ }^{6}$
}

\begin{abstract}
Many public venues such as farms, fairs, and petting zoos encourage animal contact for both educational and entertainment purposes. However, healthy farm animals, including cattle, small ruminants, and poultry, can be reservoirs for enteric zoonotic pathogens, with human infections resulting in nausea, vomiting, diarrhea, and, in some cases, severe complications that can lead to death. As animals shed these organisms in their feces, contamination of themselves and their surroundings is unavoidable. The majority of North Americans reside in urban and suburban settings, and the general public often possess limited knowledge of agricultural practices and minimal contact with farm animals. Furthermore, there is a lack of understanding of zoonotic pathogens, particularly how these pathogens are spread and the human behaviors that may increase the risk of infection. Human risk behaviors include hand-to-mouth contact immediately after physical contact with animals and their environments, a practice that facilitates the ingestion of pathogens. It is often young children who become ill due to their under-developed immune systems and poorer hygienic practices compared with adults, such as more frequent hand-to-mouth behaviors, and infrequent or improper hand washing. These illnesses are often preventable, simply through adequate hygiene and hand washing. Our objective was to use a structured approach to review the main causal organisms responsible for human illnesses acquired in petting zoo and open farm environments, Shiga toxinproducing Escherichia coli, nontyphoidal Salmonella, Campylobacter, and Cryptosporidium. Notable outbreaks involving direct contact with farm animals and farm, fair, or petting zoo environments are discussed and recommendations for how public venues can increase safety and hand hygiene compliance among visitors are proposed. The most effective protective measures against enteric illnesses include education of the public, increasing overall awareness of the risks and the importance of hand hygiene, as well as access to hand-washing facilities.
\end{abstract}

Keywords: zoonoses, Escherichia coli O157:H7, Salmonella, infectious disease, Campylobacter, Cryptosporidium, petting zoo, animal contact venue

\section{Introduction}

$\mathbf{I}^{\mathrm{N}}$ NTERACTIONS WITH ANIMALS provide numerous benefits to children and adults through education and entertainment. Many health benefits of human-animal interaction have been documented and include reduced anxiety and lowered blood pressure (Dunn et al., 2015). Contact with farm animals occurs in a variety of public settings, such as county or state agricultural fairs, farm tours or visits, livestock exhibits, petting zoos, and rodeos (Pickering et al.,
2008). Such events can be "agri-tourism" activities offered on farms, or in other agricultural settings for entertainment or educational purposes. Agri-tourism has benefits for both farmers and the public, including educating the public about agriculture and food production, developing interaction between visitors and farmers, improving relationships between farmers and the local community, and sharing agricultural heritage and rural lifestyles.

Despite the many benefits of public agricultural events, there are also significant risks if proper hygiene measures are

\footnotetext{
${ }^{1}$ Lethbridge Agricultural Research Centre, Lethbridge, Alberta, Canada.

${ }^{2}$ Alberta Agriculture and Forestry, Lethbridge, Alberta, Canada.

${ }^{3}$ Canadian Association of Fairs and Exhibitions, Brandon, Manitoba, Canada.

${ }^{4}$ Department of Food Science, University of Manitoba, Winnipeg, Manitoba, Canada.

${ }^{5}$ United States Department of Agriculture, Agricultural Research Service, College Station, Texas.

${ }^{6}$ Agriculture and Agri-Food Canada, Lethbridge Research Centre, Lethbridge, Alberta, Canada.

(c) Her Majesty the Queen in Right of Canada, as represented by the Minister of Agriculture and Agri-Food Canada.
} 
not taken. Of particular importance are zoonotic diseases (or zoonoses), which are infections transmitted between animals and humans. These infectious agents may be passed in animal feces and transmitted to humans through fecal-oral contact. Farm animals such as poultry and ruminants are important reservoirs for zoonotic pathogens (Erdozain et al., 2015).

Infants and children younger than 5 years are at the greatest risk of acquiring zoonotic pathogens from animals (Dunn et al., 2015). Often, this is due to poor hygienic practices, attraction to or curiosity about animals, and an immature or inadequate immune system (Pickering et al., 2008; Dunn et al., 2015). In many cases, the zoonotic illnesses are preventable through improved hygiene (Erdozain et al., 2015). The symptoms and consequences of these infections also tend to be more severe in infants and young children (Pickering et al., 2008). People of any age with primary or secondary immunodeficiency are at risk of more severe disease, especially pregnant women and the elderly (Pickering et al., 2008). Most frequently, zoonotic infections are of the gastrointestinal tract, with mild to severe outcomes ranging from diarrhea, abdominal cramping, and vomiting to bloody diarrhea, kidney failure, and, in some cases, death (Dunn et al., 2015).

This review addresses the main animal reservoirs and the zoonotic pathogens commonly transmitted from farm animals to humans at agricultural events, as well as the typical routes of transmission. Furthermore, this review will discuss lessons learned from outbreaks caused by zoonotic pathogens, and the important hygienic practices that can increase visitor safety.

\section{Transmission in the Farm, Fair, or Petting Zoo}

It is estimated that $60-75 \%$ of emerging infectious diseases in humans are zoonotic (Jones et al., 2008; Pickering et al., 2008), which include bacterial, viral, fungal, protozoal agents, and parasites (Hale et al., 2012). Fecal-oral transmission is considered direct when infection occurs through physical contact with an animal. Indirect transmission is also common, through routes that have an affiliation with the animal (i.e., transmission vehicle) such as aerosols, a contaminated environmental reservoir, food, or water (LeJeune and Kersting, 2010).

Carriage of zoonotic pathogens has been documented for many animal species, including domesticated pets (e.g., cats, dogs), hooved animals, ruminants, rodents, reptiles, amphibians, migratory birds, and many others (Pickering et al., 2008). Among fairs, farms, and petting zoos, the main animal reservoirs include cattle, sheep, goats, pigs, and poultry (Centers for Disease Control and Prevention, 2012a; National Association of State Public Health Veterinarians, 2013). Animal reservoirs carry pathogens in their gastrointestinal tract and shed these organisms in their feces. These hosts are often asymptomatic carriers, as they are usually healthy and show no clinical signs of illness or visible indications that they host pathogens (Baker et al., 2016).

Animal fur, hair, skin, and saliva can harbor infectious organisms due to fecal contamination (National Association of State Public Health Veterinarians, 2013). Transmission occurs when people pet, touch, feed, or are licked by animals, or when they have contacted contaminated animal bedding, flooring, barriers, or other contaminated surfaces, including strollers, clothes, and shoes (Fig. 1) (Winfield and Groisman,
2003). If the contaminated person touches their face or mucus membranes, eats, drinks, or smokes before washing their hands, their chances of ingesting pathogens and becoming ill are increased (National Association of State Public Health Veterinarians, 2013). Disease transmission can also occur in the absence of direct animal contact if a pathogen is disseminated in the environment and is ingested with dust or other fomites (Winfield and Groisman, 2003; Davis et al., 2005; Keen et al., 2006).

\section{Infections Linked to Animal Contact}

Hale et al. (2012) estimated that $14 \%$ of illnesses from seven common zoonotic pathogens were due to direct contact with farm animals. Campylobacter was responsible for $\sim 42 \%$ of these illnesses, followed by nontyphoidal Salmonella (29\%), Cryptosporidium (26\%), non-O157 Shiga toxin-producing Escherichia coli (STEC) (2\%), STEC 0157 (1\%), Yersinia enterocolitica $(<0.5 \%)$, and Listeria monocytogenes $(<0.5 \%)$ (Hale et al., 2012). Salmonella, Campylobacter, and Cryptosporidium are responsible for the majority of hospitalizations and deaths (Hale et al., 2012).

Although the transmission of STEC infections is low compared with other zoonotic pathogens, it is a significant issue because of its very small infective dose (as few as 10 cells), and the severity of illness that can develop, particularly in young children (Baker et al., 2016). Serotype O157:H7 is a particularly dangerous STEC strain; however, the top 6 nonO157 STEC serogroups causing human disease include O26, O45, O103, O111, O121, and O145 (Brooks et al., 2005; Luna-Gierke et al., 2014; Baker et al., 2016). An estimated $8 \%$ and $6 \%$ of non-O157 and O157 STEC ( $\sim 10,000$ and 6000 cases), respectively, are due to direct animal contact in the United States annually (Hale et al., 2012). Hale et al. (2012) estimated that each year, 230 hospitalizations and 2 deaths could be attributed to STEC infections arising from direct animal contact.

Campylobacter, the zoonotic pathogen responsible for the majority of illnesses, also has a very low infectious dose (a few hundred cells) (Humphrey et al., 2007). An estimated $17 \%$ of Campylobacter infections (nearly 190,000 illnesses) are due to direct contact with animals, resulting in 1877 hospitalizations and 17 deaths in the United States each year (Hale et al., 2012).

Nontyphoidal Salmonella is another zoonotic pathogen that is usually associated with the ingestion of contaminated food, with an estimated 9-11\% (127,000 cases) of all Salmonella cases attributed to direct animal contact, with another $13 \%$ acquired through environmental sources (Hoelzer et al., 2011; Hale et al., 2012). It has been estimated that Salmonella infections acquired through direct animal contact are responsible for up to 2392 hospitalizations and 47 deaths in the United States each year (Hale et al., 2012). The infective dose for nontyphoidal Salmonella is estimated at $10^{3}$ cells (Public Health Agency of Canada, 2011), with more than $20 \%$ of clinical cases in the United States occurring in children younger than 5 years (Hoelzer et al., 2011).

The protozoan pathogen Cryptosporidium parvum is commonly found in animals, with ruminants being an important reservoir (Ryan et al., 2014). Studies identified the touching or handling of farm animals, cattle in particular, as the foremost risk factor for C. parvum infection in humans 


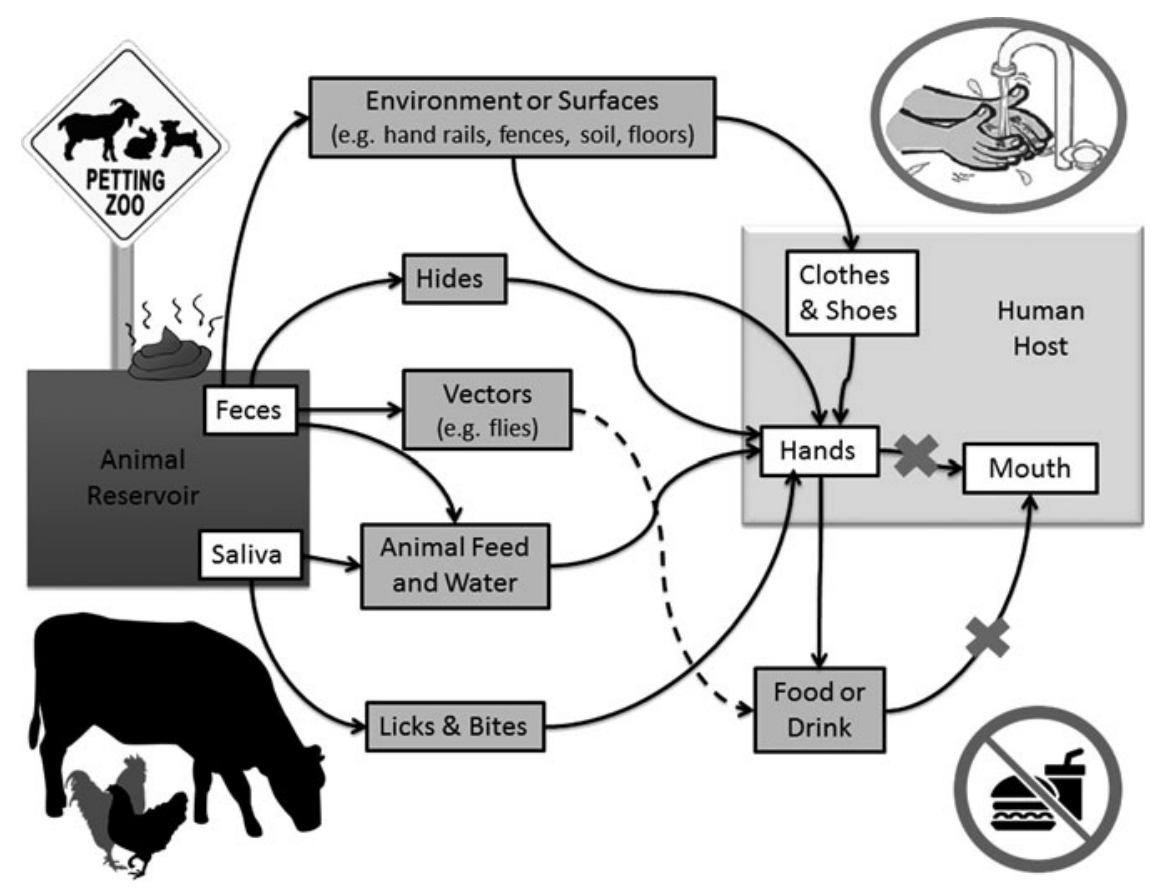

FIG. 1. Potential transmission routes for pathogens from animals to humans within an animal environment (including farms, fairs, and petting zoos). Important control points are indicated by an X symbol, namely hand washing before any hand-to-mouth behaviors and the absence of food or drink within the animal area.

(Hunter and Thompson, 2005; Hunter et al., 2007). An estimated $16 \%(113,000)$ of all Cryptosporidium infections are due to animal contact, with more than 400 hospitalizations and 7 deaths in the United States each year (Hale et al., 2012).

\section{Animal Reservoirs}

Carriage of STEC by cattle and sheep can range from low to very high $\left(\geq 10^{4}\right.$ colony-forming units [CFU]/g of feces) (McPherson et al., 2015; Baker et al., 2016). Individual cattle or small ruminants that shed more than $10^{4} \mathrm{CFU} / \mathrm{g}$ feces are termed super-shedders (Baker et al., 2016). Though only a few individuals within a herd or flock may be super-shedders, they can be responsible for widespread animal-to-animal transmission and contamination of the environment (Baker et al., 2016). One study estimated that $96 \%$ of all E. coli O157:H7 shed by a group of cattle arose from only $9 \%$ of the individuals in the herd (Omisakin et al., 2003). Identification of super-shedders can be difficult, as shedding of STEC levels $\geq 10^{4} \mathrm{CFU} / \mathrm{g}$ appears to be highly intermittent (McPherson et al., 2015; Munns et al., 2015).

Many human cases of Salmonella have also been traced back to cattle. Salmonella prevalence estimates in cattle are variable, with estimates of between-herd prevalence of 2$42 \%$ and within-herd estimates of $0-37 \%$ (Hoelzer et al., 2011). Research suggests that Salmonella prevalence varies significantly by geographical region, with a lower prevalence in the northern U.S. states and Canada than in the southern states (Besser et al., 2000; Sorensen et al., 2002). Cattle commonly shed Salmonella serovars Typhimurium and Dublin and may shed $10^{3}-10^{5} \mathrm{CFU} / \mathrm{g}$ of feces (Gopinath et al., 2012). A considerable number of Salmonella serotypes fre- quently isolated from humans have been isolated from both sick and clinically healthy cattle.

Several outbreaks have been linked to direct contact with cattle in public settings, including farm visits, fairs, petting zoos, and farm day camps in the United States (Hoelzer et al., 2011). C. parvum is often associated with cattle, particularly in suckling calves (Scott et al., 1995; O'Handley et al., 1999; Santín et al., 2004; Fayer et al., 2006). Cryptosporidium infection begins with ingestion of sporulated oocysts, the thickwalled and environmentally hardy stage of the life cycle. Cattle may shed up to $10^{4}$ oocysts/g of feces (Scott et al., 1994), and human infections may result from as few as 10 oocysts (Ryan et al., 2014). Campylobacter has also been associated with cattle (Harvey et al., 2004; Bolton et al., 2012), with cows shedding an estimated $1.1 \times 10^{2} \mathrm{CFU} / \mathrm{g}$ of feces and calves shedding nearly 250 -fold more $\left(2.7 \times 10^{4}\right.$ CFU/g of feces) (Nielsen, 2002).

Poultry are a natural host of Campylobacter jejuni, and they are responsible for an estimated $80 \%$ of human campylobacteriosis cases (Bolton, 2015). This bacteria colonizes the cecal mucosa of birds where populations can exceed $10^{8}$ CFU/g (Bolton, 2015). Salmonella spp. are also commonly detected in birds, particularly chickens and their hatchlings (Centers for Disease Control and Prevention, 2012b). Salmonella serovars carried by chickens include Enteritidis and Typhimurium, and shedding levels can range from $10^{1}$ to $10^{7}$ CFU/g of cecum (Gopinath et al., 2012). Numerous Salmonella serotypes have also been isolated from a variety of nondomesticated birds, including pigeons, doves, parrots, and parakeets (Hoelzer et al., 2011).

Small ruminants and pigs are also important reservoirs of E. coli, Salmonella, Campylobacter, and Cryptosporidium species (Gopinath et al., 2012; National Association of State 
Public Health Veterinarians, 2013; Bolton, 2015). Transmission of Salmonella from small ruminants and pigs to humans has also been reported, particularly through occupational exposure (Hoelzer et al., 2011; Daly and Hill, 2016).

Reptiles, amphibians, and fish have also been implicated as sources of human zoonotic salmonellosis (Hoelzer et al., 2011). It has been estimated that $90 \%$ of captive reptiles carry Salmonella (Woodward et al., 1997).

Management factors can also increase the risk of pathogen transmission at animal exhibits. For example, animals are more likely to shed pathogens due to stress from prolonged transportation, confinement, crowding, and increased handing by humans (Williams and Newell, 1970; Isaacson et al., 1999; Hurd et al., 2002; Dowd et al., 2007). Comingling of animals increases the likelihood of animal-to-animal transmission of pathogens (Rostagno, 2009). Certain pathogens (e.g., Salmonella) are more prevalent in younger than older animals, which are often used in petting zoos and educational programs for children (National Association of State Public Health Veterinarians, 2013). Shedding of STEC and Salmonella organisms has been shown to be highest during the summer and fall months, when the majority of animal exhibits, fairs, and petting zoos occur (Edrington et al., 2006; Menrath et al., 2010). Some pathogens shed by animals may remain viable and pose an infectious risk for months or even years in feces (Rahn et al., 1997; Sandvang et al., 2000; Baloda et al., 2001; Brown et al., 2002; Renter et al., 2003; LeJeune et al., 2004; Callaway et al., 2005) and the environment (Dunn et al., 2015). In one study, STEC O157:H7 was recovered from sawdust on a barn floor 42 weeks after an agricultural fair (Varma et al., 2003).

\section{Zoonotic Pathogen Prevalence in Farm, Fair, and Petting Zoo Animals}

Relatively few studies have examined the prevalence of STEC in fair and petting zoo livestock in North America. A study of 12 U.S. county fairs found E. coli $\mathrm{O} 157$ in $11 \%$ of cattle manure samples and $75 \%$ of the fairs (Cho et al., 2006). Nearly 3000 livestock fecal samples from county and state fairs in 2 U.S. states (Keen et al., 2006) demonstrated that STEC O157:H7 was isolated from livestock at $31(96.9 \%)$ of the 32 fairs. Prevalence of STEC O157:H7 was the highest from cattle $(11.4 \%)$, followed by sheep and goats (3.6\%), and swine $(1.2 \%)$. Flies were also collected from each fair, and $5.2 \%$ of the 154 samples collected were positive for O157:H7 (Keen et al., 2006). Other researchers detected STEC O157:H7 in pig feces at a livestock fair in California (Roug et al., 2013). In a study of 15 animal species in a petting zoo, STEC were detected in 7 goats and 3 cows (DebRoy and Roberts, 2006). To date, the prevalence of the top 6 non-O157 STEC serogroups in fairs and petting zoos has not been studied.

The prevalence of Salmonella in farms, fairs, and petting zoos has only been examined in a small number of studies. Salmonella were present in more than $50 \%$ of the samples collected from poultry exhibits at several agricultural fairs in Colorado (Pabilonia et al., 2014), and at least one environmental sample was positive for Salmonella at 10 of 11 fairs (Pabilonia et al., 2014). Another study examined the prevalence of Salmonella in feces collected from 997 animals in 36 animal exhibits and found that $0.6 \%$ of goats, $1.7 \%$ of equids, and $2 \%$ of cattle were positive (Keen et al., 2007). Salmonella was isolated from $7 \%$ of pigs and $2 \%$ of chickens at a California county fair (Roug et al., 2013).

Based on a meta-analysis of seven studies from around the world, the mean prevalence of Campylobacter among petting zoo animals was $6.5 \%$ (Pintar et al., 2015). In the Netherlands, feces from nearly $65 \%$ of petting farms were found to contain STEC $\mathrm{O} 157$ and/or Salmonella and/or Campylobacter species (Heuvelink et al., 2007).

Roug et al. (2013) screened 152 fecal samples from animals at a county fair in California and found that none tested positive for Cryptosporidium. Another study screened stool samples from 129 zoo animals and found Cryptosporidium in a wildebeest, prairie bison, and tortoise (Alves et al., 2005). Though data directly from fairs and petting zoos are limited, studies of North American dairy farms found Cryptosporidium on more than $90 \%$ of farms and indicated that even healthy calves shed the pathogen in their feces (LeJeune and Davis, 2004).

Special consideration should be taken when interpreting pathogen prevalence. First, the carriage of a pathogen species by an animal does not preclude the simultaneous carriage of other pathogens (Smith et al., 2004). Second, prevalence of pathogens and strains may differ among animals of the same species, among herds, and across geographical regions (Omisakin et al., 2003; Putignani and Menichella, 2010; Kagambèga et al., 2013). Finally, pathogens such as E. coli O157:H7 and Salmonella are often shed intermittently, thereby complicating their detection and estimates of prevalence (Pickering et al., 2008; Menrath et al., 2010).

\section{Outbreaks in Public Settings Due to Contact with Animals in Farm, Fair, or Petting Zoo Environments}

Although the majority of enteric zoonotic outbreaks occur as a result of contaminated food or water, numerous outbreaks have been traced back to direct contact with animals or indirect contact via fair, farm, and petting zoo environments (Hale et al., 2012). The first recorded outbreaks of STEC O157 associated with an animal exhibit occurred in England (1994), affecting seven individuals, with four developing Hemolytic Uremic Syndrome (HUS), followed by Wales (1995) with another three individuals affected with one developing HUS (LeJeune and Davis, 2004). Most of the victims were children, all of whom had previously visited farms. Investigations into the farms revealed inadequate handwashing facilities and over-crowded animals. Furthermore, no information was provided to visitors regarding the risks of zoonoses, and children were allowed direct contact with the animals under limited supervision (LeJeune and Davis, 2004).

Between 1996 and 2012, 200 human infectious disease outbreaks involving animals in public settings were reported to the Centers for Disease Control and Prevention (CDC) (National Association of State Public Health Veterinarians, 2013). Table 1 summarizes the North American outbreaks traced back to direct contact with livestock or poultry, or indirect contact with animals in a fair, farm, or petting zoo environment between 1995 and 2015. This table includes 81 outbreaks, with 41 linked to E. coli O157, 4 to non-O157 STEC, 21 to Salmonella, 6 to Campylobacter, 6 to Cryptosporidium, and 3 to multi-pathogen events.

A notable outbreak linked to O157:H7 occurred in Ontario, Canada (1999), where a petting zoo was associated with 155 


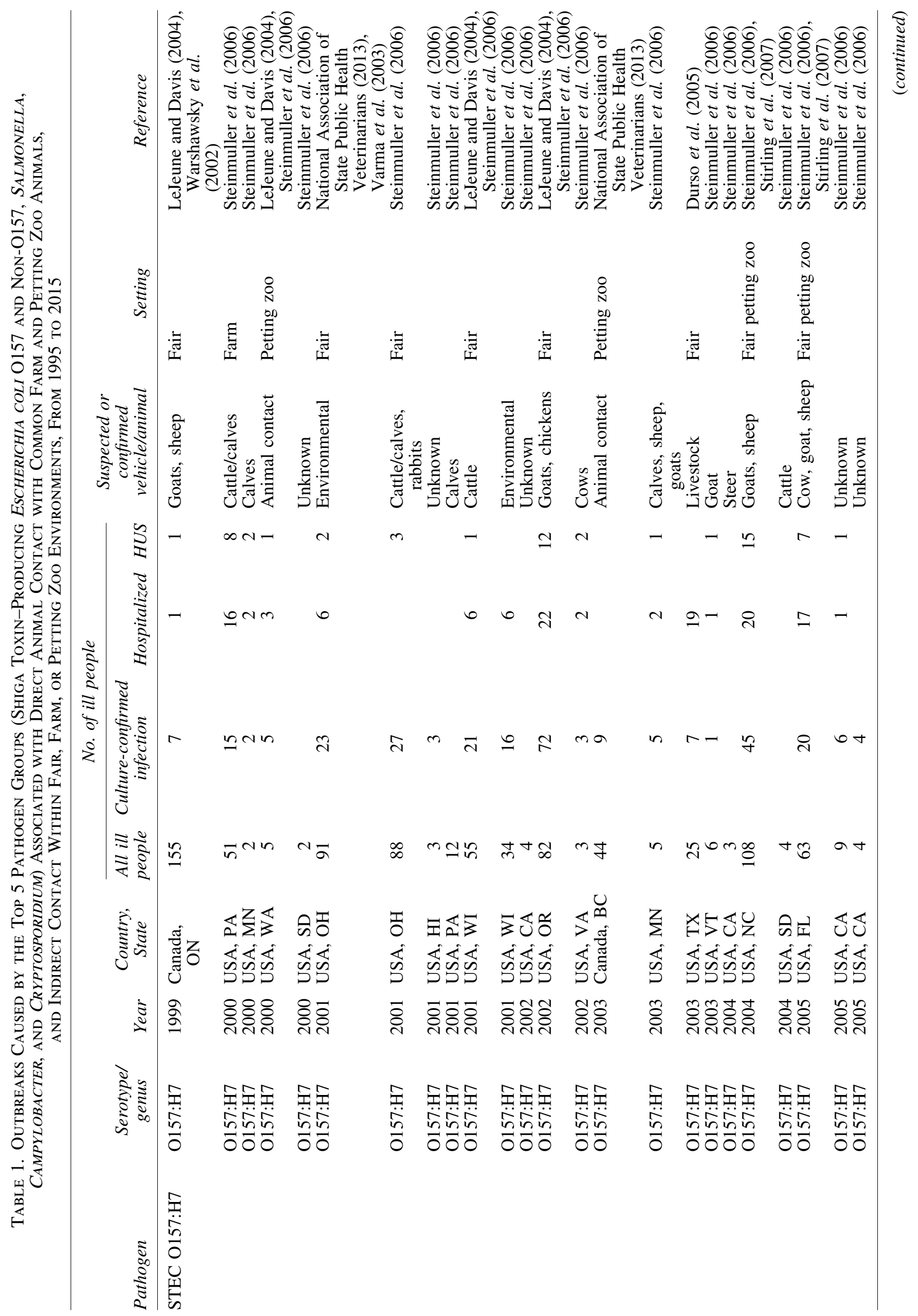




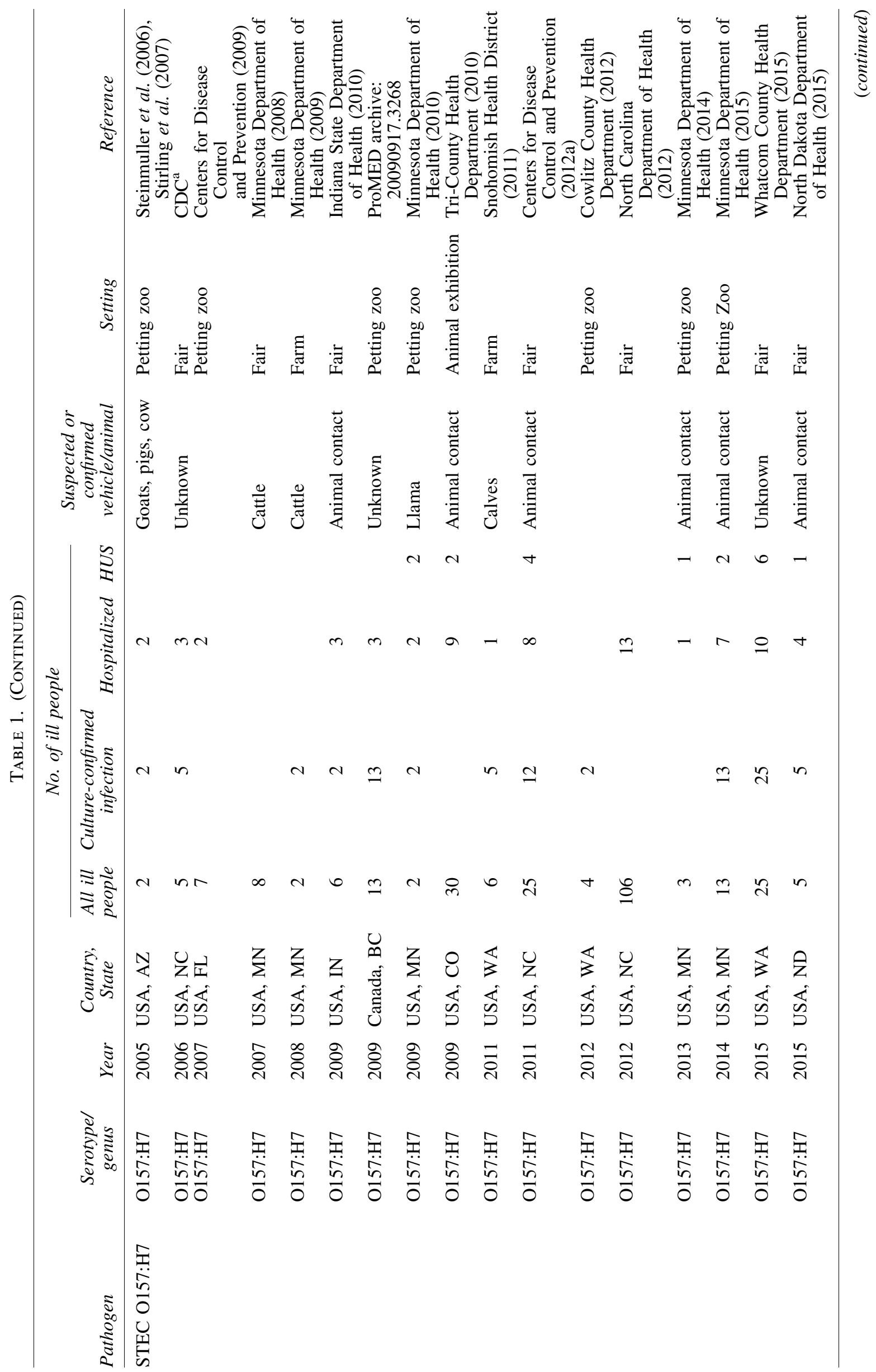




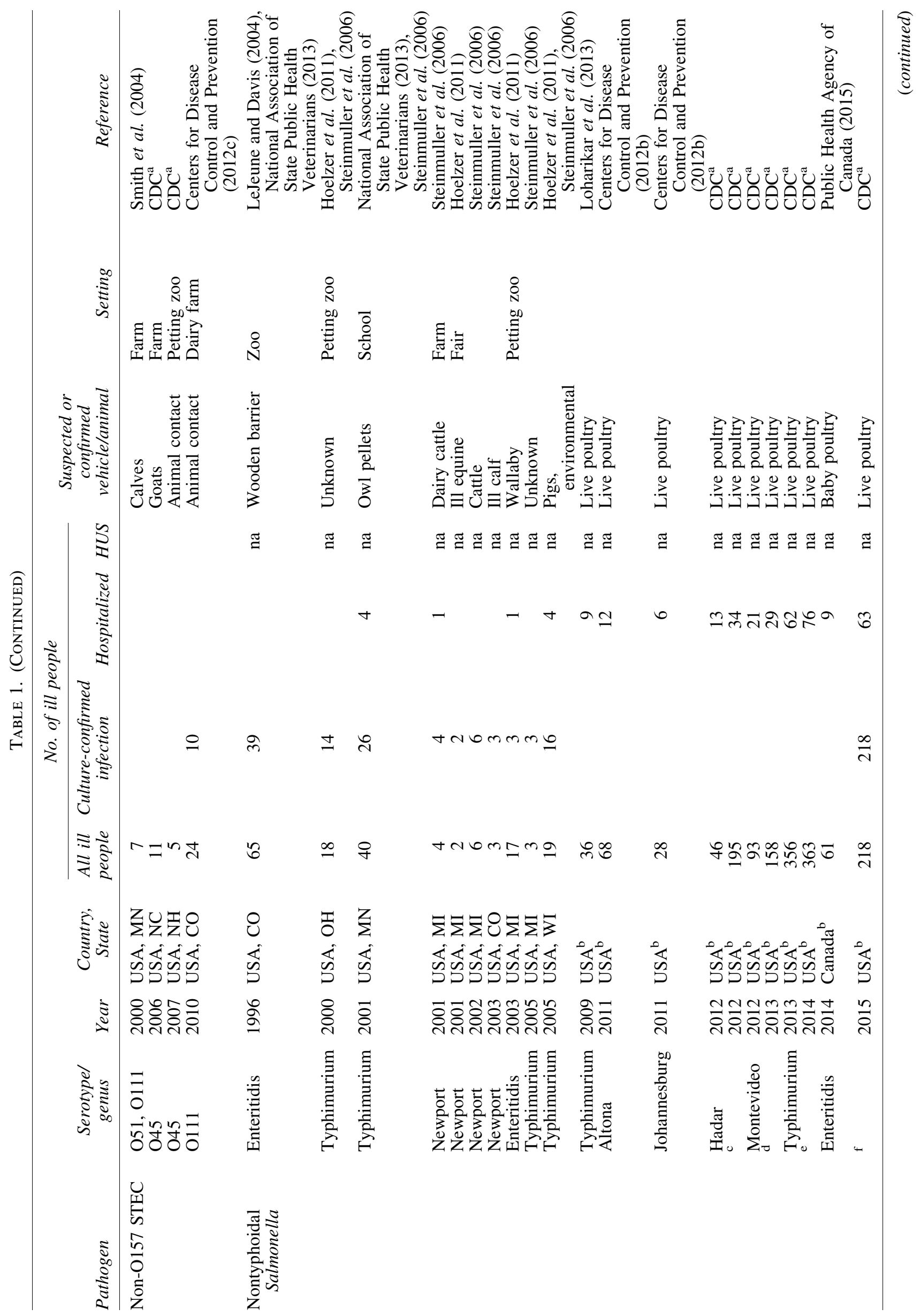




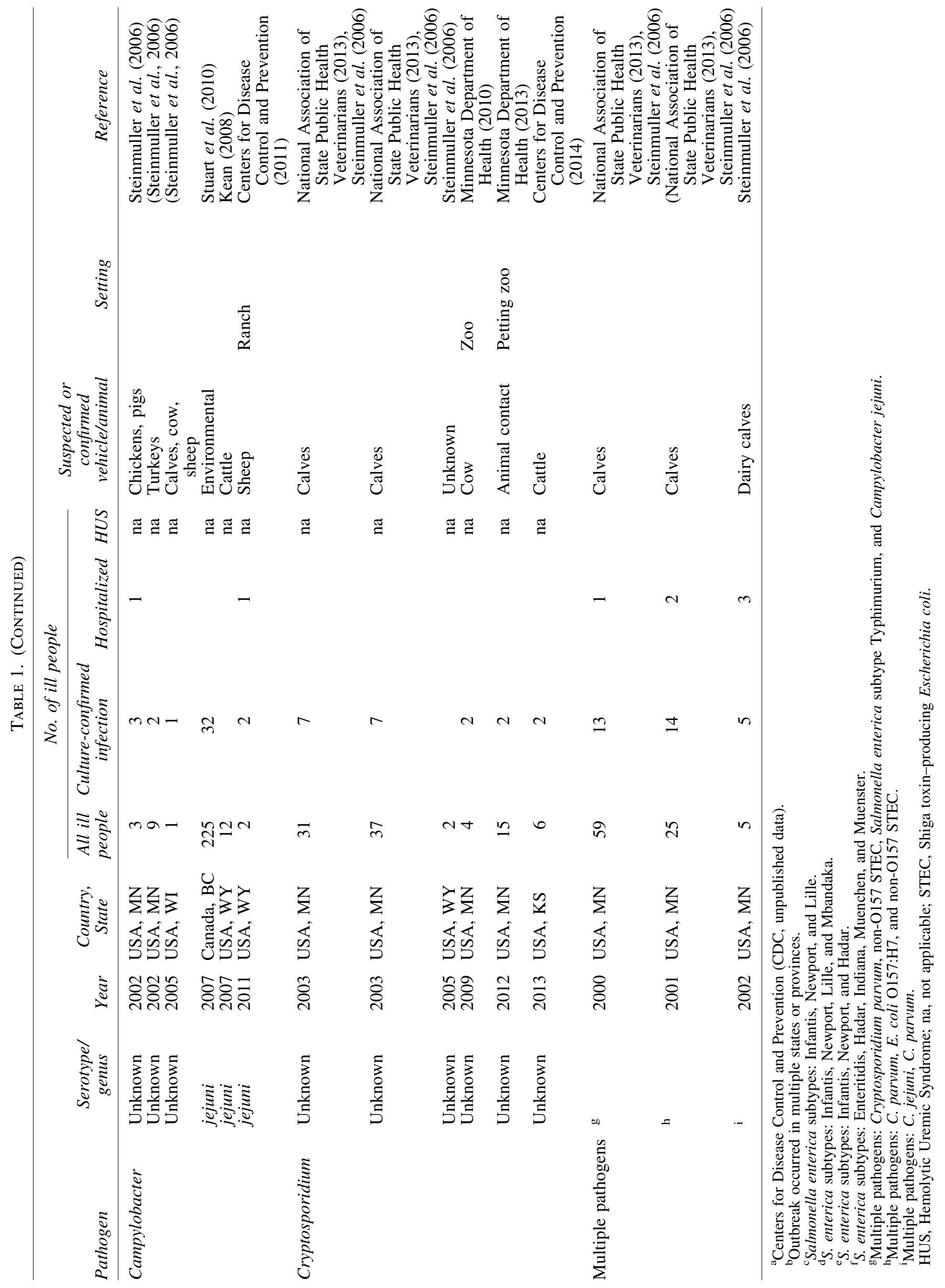


probable cases and 7 culture-confirmed infections (Warshawsky et al., 2002). Risk of infection was associated with direct contact with sheep and goats, a lack of hand washing, and eating within the animal area (LeJeune and Davis, 2004).

Two STEC outbreaks in 2000 were also associated with direct animal contact at open farms, one in Pennsylvania and the other in Washington State (Steinmuller et al., 2006). In the Pennsylvania outbreak, 51 people became ill (median age, 4 years) and 8 developed HUS (National Association of State Public Health Veterinarians, 2013). Investigation into the Pennsylvania outbreak revealed that $15 \%$ of cattle shed O157:H7 in feces. Most of the children involved were preschoolers, and there were no restrictions on eating or drinking in the animal area, nor was there supervision of animal contact (LeJeune and Davis, 2004).

Another noteworthy outbreak occurred at the North Carolina State Fair in 2004, where 108 STEC 0157:H7 cases were reported (41 laboratory-confirmed), with 20 patients hospitalized and 15 developing HUS (Goode et al., 2009). A laboratory investigation concluded that E. coli $\mathrm{O} 157: \mathrm{H} 7$ in sheep and goat feces were responsible for contamination of the petting zoo environment (Stirling et al., 2007; Goode et al., 2009).

The majority of North American Salmonella outbreaks in the past decade have involved live poultry, including a large outbreak in Canada that sickened at least 61 and hospitalized 9 people across 5 provinces (Public Health Agency of Canada, 2015). In the United States, outbreaks of salmonellosis have been associated with live poultry (e.g., chicks, chickens, ducklings, ducks, geese, turkeys) (Hale et al., 2012), totaling more than 1600 cases, 334 hospitalizations, and at least 3 deaths since 2009 (Centers for Disease Control and Prevention, 2012b; Loharikar et al., 2013). Exposure in some of these outbreaks was in nonpublic settings, but a number of ill people reported contact with live poultry in feed stores, schools, day care facilities, nursing homes, or petting zoos (National Association of State Public Health Veterinarians, 2013).

Though not specifically associated with petting zoos, several outbreaks of Salmonella have originated from direct contact with nontraditional pets (e.g., hedgehogs, mice, guinea pigs) (Hoelzer et al., 2011), as well as with reptiles and amphibians (e.g., small turtles, snakes, lizards, frogs) (National Association of State Public Health Veterinarians, 2013).

A number of outbreaks are listed as multiple-pathogen outbreaks where illnesses were attributed to two or more pathogens. Two multiple-pathogen outbreaks occurred in Minnesota during 2000 and 2001, infecting 84 people and including STEC O157:H7, non-O157 STEC strains, C. parvum, Salmonella enterica serotype Typhimurium, and $C$. jejuni (Smith et al., 2004). All of these organisms were identified in calves, and risk factors for children included caring for an ill calf, and getting a visible amount of manure on their hands (National Association of State Public Health Veterinarians, 2013).

\section{Vaccination and Antimicrobial Treatment for Zoonotic Pathogens}

This section covers some key biosecurity measures that should be considered by the owners and caretakers of animals participating in public events. Importantly, removing visibly ill animals is not sufficient to protect the health of animals and humans, since animals usually exhibit no clinical signs as a result of shedding zoonotic pathogens (National Association of
State Public Health Veterinarians, 2013). Some vaccines for zoonotic pathogens are either commercially available or in development. One vaccine against $E$. coli $\mathrm{O} 157: \mathrm{H} 7$ was fully licensed in Canada, but is no longer available, and two vaccines are available in the United States with restricted licenses (Matthews et al., 2013). However, these vaccines are rarely used in ruminant livestock (Matthews et al., 2013), as producers bear the cost of vaccination yet receive no direct economic benefit as the animals are clinically healthy (Matthews et al., 2013).

Vaccination of cattle against E. coli $\mathrm{O} 157: \mathrm{H} 7$ has been reviewed recently (Snedeker et al., 2012; Matthews et al., 2013; Varela et al., 2013). Whether vaccination could be an effective public health control measure for animal exhibits and petting zoos is unclear. Research indicates that vaccination does not consistently reduce prevalence of STEC O157:H7 in cattle feces, and additional development is required (Stanford et al., 2014). Comparisons of multiple studies indicate significant heterogeneity in the results, suggesting differential responses to vaccination across trials (Snedeker et al., 2012). In addition, vaccination may reduce but not eliminate the pathogen, making it necessary to employ a suite of interventions to reduce zoonotic risk (Snedeker et al., 2012). Currently, no vaccines for $E$. coli $\mathrm{O} 157: \mathrm{H} 7$ in small ruminants are commercially available.

Routine testing of animals is not recommended as a reliable means of preventing infection (McMillian et al., 2007), as most pathogens are shed intermittently. In addition, the inherent limitations of laboratory tests make it difficult to rapidly identify and remove infected animals from the herd or flock. Treatment of animals with antimicrobials is also not a practical option, because it has been shown to prolong shedding and could contribute to antimicrobial resistance (Al Amri et al., 2007; Béraud et al., 2008). Antimicrobial treatment cannot reliably eliminate infection, prevent shedding, or protect against reinfection and often may fail to target the pathogen of interest (National Association of State Public Health Veterinarians, 2013).

Hygienic practices can be employed on-farm to minimize transfer of pathogens between animals and from animals to humans. These include regular cleaning and disinfection of buildings and equipment, water testing and treatment, use of appropriate feeders to prevent defecation in feed, regular disinfection of animal water and feed containers, and the use feed that is produced in a manner that avoids microbial contamination (Doyle and Erickson, 2012). Hygienic practices should be employed during both housing of animals on farms and their transportation, so as to avoid crosscontamination during transport as a result of ineffective cleaning and sanitation of transport crates, containers, trailers, and vehicles (Doyle and Erickson, 2012). For farms that have visitors on-site, provision of protective footwear or footwear cleaning facilities is recommended.

\section{Human Risk Behaviors}

Fair and event organizers, educators, petting zoo and farm staff, and visitors should be aware of risky behaviors that can facilitate exposure to and transmission of zoonotic pathogens (Erdozain et al., 2015). An observational study identified some of the most common risk behaviors performed by visitors in 13 petting zoos in the United States (Erdozain et al., 
2013). These included touching hands to face in animal areas, animals licking hands, and eating or drinking within animalcontact areas (Erdozain et al., 2013, 2015). Children touching their mouths, putting objects in their mouths, biting their nails, having contact with manure, sucking thumbs, eating, or having soiled hands and shoes during or after being in animal-contact areas have also been identified as risk factors and linked to STEC infections (Hoelzer et al., 2011).

Animal-exhibit associated outbreak investigations have consistently found a protective effect of hand washing after handling animals and before eating (Davis et al., 2006). Hand washing is a critical defense against ingestion of many pathogens; however, it is often improperly taught to young children. Proper hand washing consists of using soap and thoroughly massaging the hands, creating a lather, and scrubbing them for at least $20 \mathrm{~s}$ before rinsing with running water (warm or cold) (National Association of State Public Health Veterinarians, 2013). Hands must be dried with paper towel or hand driers, not on clothing, which could result in secondary contamination.

Alcohol-based hand sanitizers are highly effective against a range of bacterial pathogens, fungi, enveloped viruses, and certain nonenveloped viruses (Edmonds et al., 2010). Several studies have indicated that alcohol-based hand sanitizers are superior to hand washing for reducing microbial contamination, while requiring less time to use and often resulting in greater compliance than hand washing (Widmer, 2000; Girou et al., 2002; Chow et al., 2012). However, a possible contributing factor to the smaller bacterial reduction of hand washing as opposed to the use of an alcohol-based hand sanitizer is an insufficient amount of time spent scrubbing when only hand washing is used (Widmer, 2000; Girou et al., 2002; Edmonds et al., 2010; Chow et al., 2012).

Though hand sanitizers may effectively reduce hand contamination with coliform bacteria (e.g., E. coli O157:H7), these products are ineffective if hands are visibly dirty (Davis et al., 2006; Anderson and Weese, 2012). Furthermore, these alcohol-based products are ineffective against many other pathogens that maybe present within a petting zoo environment (e.g., Cryptosporidium) (Anderson and Weese, 2012). The mechanical action of hand washing as well as the cleansing properties of surfactants in soaps are believed to contribute to the better reduction of microorganisms when hands are heavily soiled (Edmonds et al., 2010). Consequently, hand sanitizers are not a suitable stand-alone replacement for hand washing, but rather best used in conjunction with this preventative measure.

During a study of 13 petting zoos in Kansas and Missouri, hand hygiene compliance of 574 visitors was observed (Erdozain et al., 2013). Only $37 \%$ of visitors attempted any type of hand hygiene. Importantly, visitors were $4.8 \times$ more likely to wash their hands when a staff member was present (Erdozain et al., 2013). Hand hygiene compliance was also observed at 36 petting zoos in Ontario, Canada (Weese et al., 2007). A compliance of $0-77 \%$ was observed (mean value $30.9 \%$ ). Increased hand hygiene compliance was observed when hand-washing stations were located near the exit (Weese et al., 2007).

A subsequent study of a single petting zoo in Ontario found hand hygiene compliance to be $58 \%$ (Anderson and Weese, 2012). The most effective hand hygiene intervention observed in this study was a combination of improved signage for hand washing and petting zoo personnel stationed along the exit dispensing hand sanitizer (Anderson and Weese, 2012). Verbal hand hygiene reminders by venue staff have also been associated with increased compliance (Anderson and Weese, 2012).

\section{Legal and Economic Implications of Infection in Public Contact Areas}

After several large-scale outbreaks in the United States, legislatures of the affected states enacted laws mandating standards for animal exhibition sanitation (Babcock, 2006). These laws require animal exhibit operators to promote public awareness of the risk of contracting a zoonotic disease, to provide adequate hand-cleansing facilities, and to prohibit the exhibition of animals not properly cared for by a veterinarian (Babcock, 2006). The National Association of State Public Health Veterinarians (NASPHV), in conjunction with the $\mathrm{CDC}$, published recommendations to prevent disease outbreaks in public settings with animal exhibits (National Association of State Public Health Veterinarians, 2013).

The North Carolina legislature adopted "Aedin's Law" named after a child hospitalized with HUS after a major STEC outbreak associated with a state fair (Goode et al., 2009). This law requires that animal exhibitors acquire a public permit and adopt the regulations outlined by $\mathrm{CDC} /$ NASPHV (Babcock, 2006).

Under premises liability law, the entity responsible for managing the animal exhibition has a duty to care for the visitors invited onto the property, including adequately reducing and identifying risks and by warning the visitors of the risks present (Babcock, 2006). These laws hold exhibitors to a standard of possessing a reasonable knowledge of the risks involved and as a result, a claim of ignorance is not an effective defense (Babcock, 2006).

Anecdotal reports indicate that outbreaks associated with petting zoos have substantial legal implications for the industry (McMillian et al., 2007), with some fairs having difficulty obtaining insurance, resulting in their discontinuance. These outcomes eliminate important opportunities for agricultural education and completely eliminate urban contact with farm animals (McMillian et al., 2007). Petting zoos will almost certainly be discontinued if the possibility of largescale, life-threatening outbreaks is linked to agricultural fairs (Babcock, 2006).

The economic burden of zoonotic illnesses is a result of the direct costs associated with medical care, productivity loss, and premature deaths (Scharff, 2012). Estimates of the cost of illness of STEC O157 infection also include the medical costs and productivity losses from long-term health outcomes in a subset of individuals, as well as monetized estimates of pain, suffering, and functional disability (Scharff, 2012; Sockett et al., 2014). In Canada, an estimated 22,344 cases of STEC O157 infection each year cost the country \$26.7 million (Sockett et al., 2014). Premature deaths account for a large proportion of the cost, since the majority of deaths occur in young children (Sockett et al., 2014). There are more than 37,000 additional ongoing cases, with long-term outcomes costing $\$ 377.2$ million per year, raising the total annual cost of infection to $\$ 403.9$ million (Sockett et al., 2014).

Importantly, these estimates are based on data from the National Notifiable Diseases Registry, which include cases 
from all sources, primarily foodborne. Therefore, the costs of STEC O157 illness arising from direct animal contact would only represent a fraction of total cases, as an estimated $6 \%$ arise from direct animal contact in the United States) (Hale et al., 2012).

One study estimated the burden of infection by various different pathogens on a cost-per-case basis (in U.S. dollars) (Scharff, 2012). The basic cost-of-illness model included economic estimates for medical costs, productivity losses, and illness-related mortality, with STEC O157:H7 ranking the highest at $\$ 9606$ per case. The costs per case of the other major zoonotic pathogens were as follows: Salmonella, \$4312; Cryptosporidium, \$2056; Campylobacter, \$1846; and non-O157 STEC, $\$ 896$ (Scharff, 2012). These values do not include the pain, suffering, and long-term functional disability from the illness, which combined could increase the cost per case by as much as $\$ 11,000$ (Scharff, 2012). Nonhealthcare costs are also pronounced, including class action and victim claim settlements, fines, and prosecution costs (Pennington, 2010).

\section{Best Practices for Events Encouraging Human-Animal Interactions}

The published practice recommendations by NASPHV, in conjunction with the CDC, are addressed to government agencies, educators, exhibit managers, veterinarians, and visitors (Hoelzer et al., 2011). These recommendations include encouraging good hygiene practices, improving facility design, implementing disease monitoring and prevention systems, and prohibiting high-risk contact behaviors (Hoelzer et al., 2011). Several Canadian and U.S. health authorities, including the Canadian Food Inspection Agency (CFIA) and the Centers of Disease Control and Prevention (CDC), as well as the individual provincial and state health departments, have issued notices on the causes, symptoms, and risks associated with zoonoses as well as tips for preventing illness when visiting petting zoos (Canadian Food Inspection Agency, 2012; Centers for Disease Control and Prevention, 2015).

Important elements of an animal-contact area are reviewed by Erdozain et al. (2015). Briefly, these include a separate entrance and exit to facilitate one-way flow of visitor traffic, a safe area away from the animal area to store personal belongings, transition zones to promote hand hygiene, and a service area inaccessible to the public for transport of animals and waste in and out of the animal area (Erdozain et al., 2015).

The animal-contact area itself should be isolated from other public areas, particularly eating and food-preparation areas, by fences and/or walls. Animals should be kept clean, and manure, urine, and soiled bedding should be promptly removed (Erdozain et al., 2015).

All surfaces in animal-contact areas should be cleaned daily, including, but not limited to, walkways, fencing, faucets, and sinks. Recommended disinfectants include diluted bleach (1:16 bleach:water), or quaternary ammonium compounds used as per the manufacturer's label (National Association of State Public Health Veterinarians, 2013; Erdozain et al., 2015). Furthermore, most disinfectants require at least $10 \mathrm{~min}$ of contact time to thoroughly decontaminate surfaces (Erdozain et al., 2015).

Finally, a very important preventative measure is education, particularly of event staff and visitors, as awareness of zoo- notic disease risks protects against outbreaks (National Association of State Public Health Veterinarians, 2013). A study by Hawking et al. (2013) found that a "farm hygiene" lesson improved the awareness of risks associated with microbes and steps to prevent infection by as much as $18 \%$ (Hawking et al., 2013). Educating students on bacteria as well as general and specific hygiene practices before farm visits with their class or school is recommended (Hawking et al., 2013).

\section{Zoonotic Pathogens and the Urban Consumer}

In addition to the limited knowledge of zoonotic pathogens and farm and petting zoo hygiene among the general public, there is an even broader lack of consumer knowledge surrounding contemporary agricultural practices and food production (Sharp et al., 2002). Research suggests that individuals with repeated exposure to enteric pathogens, such as those living or working on farms, may become less susceptible to infection (Belongia et al., 2003; Hale et al., 2012). However, most members of the public have no direct interaction with farms in their daily lives, and are, therefore, more susceptible. However, many will attend a farm, fair, or petting zoo in their lifetime, highlighting the importance of preventative hygiene measures. In addition, these events provide a unique opportunity for people from an urban environment to experience elements of the rural lifestyle and to interact directly with farmers. This is an excellent opportunity for education that extends beyond the risks of direct animal contact.

Farms, fairs, and petting zoos should be encouraged to provide additional education about agricultural practices, food production, and food safety. Though it is the responsibility of the health community, food industry, regulators, and the media together to educate the public about food safety, public agricultural events provide another venue to encourage familiarity with these concepts (Wilcock et al., 2004). The reality of zoonotic pathogens is that regulations cannot provide complete protection from foodborne illnesses nor those contracted from direct animal contact. Rather, education is required so that the public may realize their responsibility in ensuring their own safety.

\section{Conclusions}

Anecdotal reports of difficulty in obtaining insurance and fairs discontinuing petting zoos are increasingly common due to legal regulations and fears of zoonotic transmission (McMillian et al., 2007). As a result, opportunities for public education and interaction with animals may be lost. At this time, contamination of animal environments cannot be entirely eliminated. However, the risks associated with direct animal contact and enteric pathogens can be reduced with appropriate sanitary practices and education. Therefore, the implementation of the recommendations outlined by the health authorities and NASPHV, such as promoting hand washing, and avoidance of risk behaviors like eating and drinking in animal areas, are critical to ensure that opportunities for human-animal interaction remain under minimal risk conditions (McMillian et al., 2007).

Additional research on pathogen incidence in fair and petting zoos, and development of training sessions and educational materials for fair and petting zoo operators would be beneficial steps toward improving public safety in public animal venues. Such outreach activities are an important 
component of gaining the urban public's social license to operate, but only if they can be undertaken in a manner that minimizes the risks of zoonotic transmission.

\section{Methods}

The literature search was conducted from December 2015 to May 2016 by using Google Scholar, Scopus, Web of Science, and PubMed. Key words searched included Escherichia coli O157:H7, non-O157 STEC, Salmonella, Campylobacter, and Cryptosporidium, both with and without simultaneously searching the phrases petting zoo, animal exhibit/exhibition, and county/state fair. All studies acquired from the databases from 1995 mentioned earlier to those at present that described human enteric pathogens (Escherichia coli 0157:H7 and non-O157, Salmonella, Campylobacter, and Cryptosporidium) within the context of zoonotic transmission, public venues, and animal exhibitions (fairs, farms, petting zoos) were included. Studies before this year were excluded, except for where information was sparse, specifically regarding the shedding of Cryptosporidium and Salmonella organisms.

Only manuscripts in English were considered, as authors lacked the ability to interpret manuscripts presented in other languages. The year 1995 was selected as the cut-off year, as relevant references were not found in the databases before this time. Studies that possessed these key words and were relevant to the topic area were selected. Data were excepted, as they were presented within peer-reviewed manuscripts. Where nonpeer reviewed health reports were cited, the appropriate web address to access the reports was included.

\section{Acknowledgments}

The authors wish to express their appreciation to the $\mathrm{Ca}$ nadian Association of Fairs and Exhibitions and the Growing Forward II program of Agriculture and Agri-Food Canada for the financial support that enabled this review to be prepared.

\section{Disclosure Statement}

No competing financial interests exist.

\section{References}

Al Amri A, Senok AC, Ismaeel AY, Al-Mahmeed AE, Botta GA. Multiplex PCR for direct identification of Campylobacter spp. in human and chicken stools. J Med Microbiol 2007;56:1350-1355.

Alves M, Xiao L, Lemos V, Zhou L, Cama V, da Cunha MB, Matos O, Antunes F. Occurrence and molecular characterization of Cryptosporidium spp. in mammals and reptiles at the Lisbon Zoo. Parasitol Res 2005;97:108-112.

Anderson ME, Weese JS. Video observation of hand hygiene practices at a petting zoo and the impact of hand hygiene interventions. Epidemiol Infect 2012;140:182-190.

Babcock DW. Legal implications of zoonotic-disease outbreaks at petting zoos and animal exhibits. J Environ Health 2006; 69:46-47.

Baker CA, Rubinelli PM, Park SH, Carbonero F, Ricke SC. Shiga toxin-producing Escherichia coli in food: Incidence, ecology, and detection strategies. Food Control 2016;59:407-419.

Baloda SB, Christensen L, Trajcevska S. Persistence of a Salmonella enterica serovar Typhimurium DT12 clone in a piggery and in agricultural soil amended with Salmonella- contaminated slurry. Appl Environ Microbiol 2001;67:2859_ 2862.

Belongia EA, Chyou P-H, Greenlee RT, Perez-Perez G, Bibb WF, DeVries EO. Diarrhea incidence and farm-related risk factors for Escherichia coli O157:H7 and Campylobacter jejuni antibodies among rural children. J Infect Dis 2003;187: 1460-1468.

Béraud R, Huneault L, Bernier D, Beaudry F, Letellier A, del Castillo JRE. Comparison of the selection of antimicrobial resistance in fecal Escherichia coli during enrofloxacin administration with a local drug delivery system or with intramuscular injections in a swine model. Can J Vet Res 2008;72:311-319.

Besser TE, Goldoft M, Pritchett LC, Khakhria R, Hancock DD, Rice DH, Gay JM, Johnson W, Gay CC. Multiresistant Salmonella Typhimurium DT104 infections of humans and domestic animals in the Pacific Northwest of the United States. Epidemiol Infect 2000;124:193-200.

Bolton DJ. Campylobacter virulence and survival factors. Food Microbiol 2015;48:99-108.

Bolton DJ, O'Neill CJ, Fanning S. A preliminary study of Salmonella, verocytotoxigenic Escherichia coli/Escherichia coli $\mathrm{O} 157$ and Campylobacter on four mixed farms. Zoonoses Public Health 2012;59:217-228.

Brooks JT, Sowers EG, Wells JG, Greene KD, Griffin PM, Hoekstra RM, Strockbine NA. Non-O157 Shiga toxinproducing Escherichia coli infections in the United States, 1983-2002. J Infect Dis 2005;192:1422-1429.

Brown MRW, Smith AW, Barker J, Humphrey TJ, Dixon B, Reilly WJ. E. coli O157 persistence in the environment. Microbiology 2002;148:1-2.

Callaway TR, Morrow JL, Johnson AK, Dailey JW, Wallace FM, Wagstrom EA, McGlone JJ, Lewis AR, Dowd SE, Poole TL, Edrington TS, Anderson RC, Genovese KJ, Byrd JA, Harvey RB, Nisbet DJ. Environmental prevalence and persistence of Salmonella spp. in outdoor swine wallows. Foodborne Pathog Dis 2005;2:263-273.

Canadian Food Inspection Agency. Pets and petting zoos. Tips for preventing illness. 2012. Available at: www.inspection.gc .ca/food/information-for-consumers/fact-sheets-and-infographics/ food-handling/pets-and-petting-zoos/eng/1331585959444/ 1331586128326, accessed May 24, 2016.

Centers for Disease Control and Prevention. Outbreak of Shiga toxin-producing Escherichia coli $\mathrm{O} 157$ infection associated with a day camp petting zoo-Pinellas County, Florida, MayJune 2007. 2009. Available at: www.cdc.gov/mmwr/preview/ mmwrhtml/mm5816a3.htm, accessed February 4, 2016.

Centers for Disease Control and Prevention. Notes from the field: Campylobacter jejuni infections associated with sheep castration. 2011. Available at: www.cdc.gov/mmwr/preview/ mmwrhtml/mm6048a4.htm, accessed January 14, 2016.

Centers for Disease Control and Prevention. Notes from the field: Escherichia coli O157:H7 gastroenteritis associated with a state fair-North Carolina, 2011. 2012a. Available at: www.cdc.gov/mmwr/preview/mmwrhtml/mm6051a5.htm, accessed January 14, 2016.

Centers for Disease Control and Prevention. Notes from the field: Multistate outbreak of Salmonella Altona and Johannesburg infections linked to chicks and ducklings from a mail-order hatchery-United States, February-October 2011. 2012b. Available at: www.cdc.gov/mmwr/preview/mmwrhtml/ mm6111a5.htm, accessed February 5, 2016.

Centers for Disease Control and Prevention. Outbreak of Shiga toxin-producing Escherichia coli O111 infections associated with a correctional facility dairy-Colorado, 2010. 2012c. 
Available at: www.cdc.gov/mmwr/preview/mmwrhtml/ mm6109a1.htm, accessed February 5, 2016.

Centers for Disease Control and Prevention. Outbreak of cryptosporidiosis among responders to a rollover of a truck carrying calves-Kansas, April 2013. 2014. Available at: www.cdc.gov/mmwr/preview/mmwrhtml/mm6350a1.htm, accessed February 5, 2016.

Centers for Disease Control and Prevention. Stay healthy at animal exhibits. 2015. Available at: www.cdc.gov/features/ animalexhibits, accessed May 24, 2016.

Cho S, Bender JB, Diez-Gonzalez F, Fossler CP, Hedberg CW, Kaneene JB, Ruegg PL, Warnick LD, Wells SJ. Prevalence and characterization of Escherichia coli $\mathrm{O} 157$ isolates from minnesota dairy farms and county fairs. J Food Prot 2006; 69:252-259.

Chow A, Arah OA, Chan S-P, Poh B-F, Krishnan P, Ng W-K, Choudhury S, Chan J, Ang B. Alcohol handrubbing and chlorhexidine handwashing protocols for routine hospital practice: A randomized clinical trial of protocol efficacy and time effectiveness. Am J Infect Control 2012;40:800-805.

Cowlitz County Health Department. E. coli cases linked to Willow Grove Pumpkin Patch. 2012. Available at: http:// foodpoisoningbulletin.com/wp-content/uploads/Cowlitz_EColi2012_10_26.pdf, accessed January 15, 2016.

Daly RF, Hill NT. Characterizing the role of animal exposures in Cryptosporidiosis and Shiga toxin-producing Escherichia coli infections: South Dakota, 2012. Zoonoses Public Health 2016;63:467-476.

Davis MA, Cloud-Hansen KA, Carpenter J, Hovde CJ. Escherichia coli $\mathrm{O} 157: \mathrm{H} 7$ in environments of culture-positive cattle. Appl Environ Microbiol 2005;71:6816-6822.

Davis MA, Sheng H, Newman J, Hancock DD, Hovde CJ. Comparison of a waterless hand-hygiene preparation and soapand-water hand washing to reduce coliforms on hands in animal exhibit settings. Epidemiol Infect 2006;134:1024-1028.

DebRoy C, Roberts E. Screening petting zoo animals for the presence of potentially pathogenic Escherichia coli. J Vet Diagn Invest 2006;18:597-600.

Dowd SE, Callaway TR, Morrow-Tesch J. Handling may cause increased shedding of Escherichia coli and total coliforms in pigs. Foodborne Pathog Dis 2007;4:99-102.

Doyle MP, Erickson MC. Opportunities for mitigating pathogen contamination during on-farm food production. Int $\mathbf{J}$ Food Microbiol 2012;152:54-74.

Dunn JR, Behravesh CB, Angulo FJ. Diseases transmitted by domestic livestock: Perils of the petting zoo. Microbiol Spectr 2015;3. DOI: 10.1128/microbiolspec.IOL5-0017-2015.

Durso LM, Reynolds K, Bauer N, Jr., Keen JE. Shiga-toxigenic Escherichia coli O157:H7 infections among livestock exhibitors and visitors at a Texas County Fair. Vector Borne Zoonotic Dis 2005;5:193-201.

Edmonds SL, Mann J, McCormack RR, Macinga DR, Fricker CM, Arbogast JW, Dolan MJ. SaniTwice: A novel approach to hand hygiene for reducing bacterial contamination on hands when soap and water are unavailable. J Food Prot 2010;73:2296-2300.

Edrington TS, Callaway TR, Ives SE, Engler MJ, Looper ML, Anderson RC, Nisbet DJ. Seasonal shedding of Escherichia coli $\mathrm{O} 157: \mathrm{H} 7$ in ruminants: A new hypothesis. Foodborne Pathog Dis 2006;3:413-421.

Erdozain G, KuKanich K, Chapman B, Powell D. Observation of public health risk behaviours, risk communication and hand hygiene at Kansas and Missouri petting zoos. Zoonoses Public Health 2013;60:304-310.
Erdozain G, KuKanich K, Chapman B, Powell D. Best practices for planning events encouraging human-animal interactions. Zoonoses Public Health 2015;62:90-99.

Fayer R, Santín M, Trout JM, Greiner E. Prevalence of species and genotypes of Cryptosporidium found in 1-2-year-old dairy cattle in the eastern United States. Vet Parasitol 2006; 135:105-112.

Girou E, Loyeau S, Legrand P, Oppein F, Brun-Buisson C. Efficacy of handrubbing with alcohol based solution versus standard handwashing with antiseptic soap: Randomised clinical trial. BMJ 2002;325:362.

Goode B, O’Reilly C, Dunn J, Fullerton K, Smith S, Ghneim G, Keen J, Durso L, Davies M, Montgomery S. Outbreak of Escherichia coli O157: H7 infections after petting zoo visits, North Carolina state fair, October-November 2004. Arch Pediatr Adolesc Med 2009;163:42-48.

Gopinath S, Carden S, Monack D. Shedding light on Salmonella carriers. Trends Microbiol 2012;20:320-327.

Hale CR, Scallan E, Cronquist AB, Dunn J, Smith K, Robinson T, Lathrop S, Tobin-D'Angelo M, Clogher P. Estimates of enteric illness attributable to contact with animals and their environments in the United States. Clin Infect Dis 2012;54: S472-S479.

Harvey RB, Droleskey RE, Sheffield CL, Edrington TS, Callaway TR, Anderson RC, Drinnon DL, Ziprin RL, Scott HM, Nisbet DJ. Campylobacter prevalence in lactating dairy cows in the United States. J Food Prot 2004;67:1476-1479.

Hawking MK, Lecky DM, Verlander NQ, McNulty CA. Fun on the farm: Evaluation of a lesson to teach students about the spread of infection on school farm visits. PLoS One 2013;8: e75641.

Heuvelink AE, Valkenburgh SM, Tilburg JJ, Van Heerwaarden C, Zwartkruis-Nahuis JT, De Boer E. Public farms: Hygiene and zoonotic agents. Epidemiol Infect 2007;135:1174-1183.

Hoelzer K, Moreno Switt AI, Wiedmann M. Animal contact as a source of human non-typhoidal salmonellosis. Vet Res 2011; 42:34.

Humphrey T, O'Brien S, Madsen M. Campylobacters as zoonotic pathogens: A food production perspective. Int $\mathrm{J}$ Food Microbiol 2007;117:237-257.

Hunter PR, Hadfield SJ, Wilkinson D, Lake IR, Harrison FCD, Chalmers RM. Correlation between subtypes of Cryptosporidium parvum in humans and risk. Emerg Infect Dis 2007; 13:82-88.

Hunter PR, Thompson RCA. The zoonotic transmission of Giardia and Cryptosporidium. Int J Parasitol 2005;35:1181-1190.

Hurd HS, McKean JD, Griffith RW, Wesley IV, Rostagno MH. Salmonella enterica infections in market swine with and without transport and holding. Appl Environ Microbiol 2002; 68:2376-2381.

Indiana State Department of Health. County fair ends with serious illness for some participants. 2010. Available at: www .in.gov/isdh/files/Epi_V18_N01_2010_Jan_Feb.pdf, accessed January 14, 2016.

Isaacson RE, Firkins LD, Weigel RM, Zuckermann FA, DiPietro JA. Effect of transportation and feed withdrawal on shedding of Salmonella typhimurium among experimentally infected pigs. Am J Vet Res 1999;60:1155-1158.

Jones KE, Patel NG, Levy MA, Storeygard A, Balk D, Gittleman JL, Daszak P. Global trends in emerging infectious diseases. Nature 2008;451:990-993.

Kagambèga A, Lienemann T, Aulu L, Traoré AS, Barro N, Siitonen A, Haukka K. Prevalence and characterization of Salmonella enterica from the feces of cattle, poultry, swine 
and hedgehogs in Burkina Faso and their comparison to human Salmonella isolates. BMC Microbiol 2013;13:253.

Kean AN. Wyoming Food and Water Borne Disease Occurrences. Cheyenne, Wyoming: State of Wyoming Legislature, 2008, pp. 1-9.

Keen JE, Durso LM, Meehan TP. Isolation of Salmonella enterica and Shiga-toxigenic Escherichia coli $\mathrm{O} 157$ from feces of animals in public contact areas of United States zoological parks. Appl Environ Microbiol 2007;73:362-365.

Keen JE, Wittum TE, Dunn JR, Bono JL, Durso LM. Shigatoxigenic Escherichia coli $\mathrm{O} 157$ in agricultural fair livestock, United States. Emerg Infect Dis 2006;12:780-786.

LeJeune J, Kersting A. Zoonoses: An occupational hazard for livestock workers and a public health concern for rural communities. J Agric Safe Health 2010;16:161-179.

LeJeune JT, Besser TE, Rice DH, Berg JL, Stillborn RP, Hancock DD. Longitudinal study of fecal shedding of Escherichia coli O157:H7 in feedlot cattle: Predominance and persistence of specific clonal types despite massive cattle population turnover. Appl Environ Microbiol 2004;70:377-385.

LeJeune JT, Davis MA. Outbreaks of zoonotic enteric disease associated with animal exhibits. J Am Vet Med Assoc 2004; 224:1440-1445.

Loharikar A, Vawter S, Warren K, Deasy M, 3rd, Moll M, Sandt C, Gilhousen R, Villamil E, Rhorer A, Briere E, Schwensohn C, Trees E, Lafon P, Adams JK, Le B, Behravesh CB. Outbreak of human Salmonella Typhimurium infections linked to contact with baby poultry from a single agricultural feed store chain and mail-order hatchery, 2009. Pediatr Infect Dis J 2013;32:8-12.

Luna-Gierke RE, Griffin PM, Gould LH, Herman K, Bopp CA, Strockbine N, Mody RK. Outbreaks of non-O157 Shiga toxin-producing Escherichia coli infection: USA. Epidemiol Infect 2014;142:2270-2280.

Matthews L, Reeve R, Gally DL, Low JC, Woolhouse ME, McAteer SP, Locking ME, Chase-Topping ME, Haydon DT, Allison LJ, Hanson MF, Gunn GJ, Reid SW. Predicting the public health benefit of vaccinating cattle against Escherichia coli O157. Proc Natl Acad Sci U S A 2013;110:16265-16270.

McMillian M, Dunn JR, Keen JE, Brady KL, Jones TF. Risk behaviors for disease transmission among petting zoo attendees. J Am Vet Med Assoc 2007;231:1036-1038.

McPherson AS, Dhungyel OP, Ward MP. Comparison of rectoanal mucosal swab and faecal culture for the detection of Escherichia coli $\mathrm{O} 157$ and identification of super-sheeding in a mob of Merino sheep. Epidemiol Infect 2015;143:2733-2742.

Menrath A, Wieler LH, Heidemanns K, Semmler T, Fruth A, Kemper N. Shiga toxin-producing Escherichia coli: Identification of non-O157:H7-super-shedding cows and related risk factors. Gut Pathog 2010;2:7.

Minnesota Department of Health. Annual summary of communicable disease reported to the Minnesota department of health, 2007. 2008. Available at: www.health.state.mn.us/ divs/idepc/newsletters/dcn/sum07/index.html, accessed December 8, 2015.

Minnesota Department of Health. Annual summary of communicable disease reported to the Minnesota department of health, 2008. 2009. Available at: www.health.state.mn.us/ divs/idepc/newsletters/dcn/sum08/index.html, accessed December 8, 2015.

Minnesota Department of Health. Annual summary of communicable disease reported to the Minnesota department of health, 2009. 2010. Available at: www.health.state.mn.us/ divs/idepc/newsletters/dcn/sum09/index.html, accessed December 8, 2015.

Minnesota Department of Health. Annual summary of communicable disease reported to the Minnesota department of health, 2012. 2013. Available at: www.health.state.mn.us/divs/idepc/ newsletters/dcn/sum12/index.html, accessed December 8, 2015.

Minnesota Department of Health. Annual summary of communicable disease reported to the Minnesota department of health, 2013. 2014. Available at: www.health.state.mn.us/ divs/idepc/newsletters/dcn/sum13/index.html, accessed December 8, 2015.

Minnesota Department of Health. Annual summary of communicable disease reported to the Minnesota department of health, 2014. 2015. Available at: www.health.state.mn.us/ divs/idepc/newsletters/dcn/sum14/index.html, accessed December 8, 2015.

Munns KD, Selinger L, Stanford K, Selinger LB, McAllister TA. Are super-shedder cattle really super? Foodborne Pathog Dis 2015;11:329-331.

National Association of State Public Health Veterinarians. Compendium of measures to prevent disease associated with animals in public settings. J Am Vet Med Assoc 2013;243: 1270-1288.

Nielsen EM. Occurrence and strain diversity of thermophilic campylobacters in cattle of different age groups in dairy herds. Lett Appl Microbiol 2002;35:85-89.

North Carolina Department of Health. DHHS public health investigators identify source of $E$. coli outbreak. 2012. Available at: www2.ncdhhs.gov/pressrel/2012/2012-11-09_ecoli_source. htm, accessed February 5, 2016.

North Dakota Department of Health. Health department investigating cluster of $E$. coli cases. 2015. Available at: www .ndhan.gov/media/alerts, accessed January 12, 2016.

O'Handley RM, Cockwill C, McAllister TA, Jelinski M, Morck DW, Olson ME. Duration of naturally acquired giardiosis and cryptosporidiosis in dairy calves and their association with diarrhea. J Am Vet Med Assoc 1999;214:391-396.

Omisakin F, MacRae M, Ogden ID, Strachan NJC. Concentration and prevalence of Escherichia coli $\mathrm{O} 157$ in cattle feces at slaughter. Appl Environ Microbiol 2003;69:2444-2447.

Pabilonia KL, Cadmus KJ, Lingus TM, Bolte DS, Russell MM, Van Metre DC, Erdman MM. Environmental Salmonella in agricultural fair poultry exhibits in Colorado. Zoonoses Public Health 2014;61:138-144.

Pennington H. Escherichia coli O157. Lancet 2010;376:14281435.

Pickering LK, Marano N, Bocchini JA, Angulo FJ; Committee on Infectious Diseases. Exposure to nontraditional pets at home and to animals in public settings: Risks to children. Pediatrics 2008;122:876-886.

Pintar KD, Christidis T, Thomas MK, Anderson M, Nesbitt A, Keithlin J, Marshall B, Pollari F. A systematic review and meta-analysis of the Campylobacter spp. prevalence and concentration in household pets and petting zoo animals for use in exposure assessments. PLoS One 2015;10:e0144976.

Public Health Agency of Canada. Salmonella enterica spp. pathogen safety data sheet. 2011. Available at: www.phac-aspc.gc .ca/lab-bio/res/psds-ftss/salmonella-ent-eng.php, accessed February $4,2016$.

Public Health Agency of Canada. Outbreak of Salmonella infections related to contact with live baby poultry. 2015. Available at: www.phac-aspc.gc.ca/phn-asp/2015/salmonellaeng.php, accessed February 5, 2016. 
Putignani L, Menichella D. Global distribution, public health and clinical impact of the protozoan pathogen Cryptosporidium. Interdiscip Perspect Infect Dis 2010;2010:753512.

Rahn K, Renwick SA, Johnson RP, Wilson JB, Clarke RC, Alves D, McEwen S, Lior H, Spika J. Persistence of Escherichia coli $\mathrm{O} 157: \mathrm{H} 7$ in dairy cattle and the dairy farm environment. Epidemiol Infect 1997;119:251-259.

Renter DG, Sargeant JM, Oberst RD, Samadpour M. Diversity, frequency, and persistence of Escherichia coli O157 strains from range cattle environments. Appl Environ Microbiol 2003;69:542-547.

Rostagno MH. Can stress in farm animals increase food safety risk? Foodborne Pathog Dis 2009;6:767-776.

Roug A, Byrne BA, Conrad PA, Miller WA. Zoonotic fecal pathogens and antimicrobial resistance in county fair animals. Comp Immunol Microbiol Infect Dis 2013;36:303-308.

Ryan U, Fayer R, Xiao L. Cryptosporidium species in humans and animals: Current understanding and research needs. Parasitology 2014;141:1667-1685.

Sandvang D, Jensen LB, Baggesen DL, Baloda SB. Persistence of a Salmonella enterica serotype Typhimurium clone in Danish pig production units and farmhouse environment studied by pulsed field gel electrophoresis (PFGE). FEMS Microbiol Lett 2000;187:21-25.

Santín M, Trout JM, Xiao L, Zhou L, Greiner E, Fayer R. Prevalence and age-related variation of Cryptosporidium species and genotypes in dairy calves. Vet Parasitol 2004; 122:103-117.

Scharff RL. Economic burden from health losses due to foodborne illness in the United States. J Food Prot 2012;75:123131.

Scott CA, Smith HV, Gibbs HA. Excretion of Cryptosporidium parvum oocysts by a herd of beef suckler cows. Vet Rec 1994; 134:172.

Scott CA, Smith HV, Mtambo MMA, Gibbs HA. An epidemiological study of Cryptosporidium parvum in two herds of adult beef cattle. Vet Parasitol 1995;57:277-288.

Sharp J, Imerman E, Peters G. Community supported agriculture (CSA): Building community among farmers and nonfarmers. J Ext 2002;40:1-6.

Smith KE, Stenzel SA, Bender JB, Wagstrom E, Soderlund D, Leano FT, Taylor CM, Belle-Isle PA, Danila R. Outbreaks of enteric infections caused by multiple pathogens associated with calves at a farm day camp. Pediatr Infect Dis J 2004;23: 1098-1104.

Snedeker KG, Campbell M, Sargeant JM. A systematic review of vaccinations to reduce the shedding of Escherichia coli O157 in the faeces of domestic ruminants. Zoonoses Public Health 2012;59:126-138.

Snohomish Health District. Shiga toxin-producing E. coli O157:H7 Outbreak Report, Forest Park Animal Farm, Everett, WA, June 2011. 2011. Available at: www.outbreakdatabase .com/reports/Forest_Park_Animal_Farm_outbreak_report.pdf, accessed February $4,2016$.

Sockett P, Goebel SE, Varela NP, Guthrie A, Wilson J, Guilbault LA, Clark WF. Verotoxigenic Escherichia coli: Costs of illness in Canada, including long-term health outcomes. J Food Prot 2014;77:216-226.

Sorensen O, Van Donkersgoed J, McFall M, Manninen K, Gensler G, Ollis G. Salmonella spp. shedding by Alberta beef cattle and the detection of Salmonella spp. in ground beef. J Food Prot 2002;65:484-491.

Stanford K, Hannon S, Booker CW, Jim GK. Variable efficacy of a vaccine and direct-fed microbial for controlling $E s$ - cherichia coli $\mathrm{O} 157: \mathrm{H} 7$ in feces and on hides of feedlot cattle. Foodborne Pathog Dis 2014;11:379-387.

Steinmuller N, Demma L, Bender JB, Eidson M, Angulo FJ. Outbreaks of enteric disease associated with animal contact: Not just a foodborne problem anymore. Clin Infect Dis 2006; 43:1596-1602.

Stirling J, Griffith M, Dooley JS, Goldsmith CE, Loughrey A, Lowery CJ, McClurg R, McCorry K, McDowell D, McMahon A, Millar BC, Rao J, Rooney PJ, Snelling WJ, Matsuda $\mathrm{M}$, Moore JE. Zoonoses associated with petting farms and open zoos. Vector Borne Zoonotic Dis 2007;8:85-92.

Stuart TL, Sandhu J, Stirling R, Corder J, Ellis A, Misa P, Goh S, Wong B, Martiquet P, Hoang L, Galanis E. Campylobacteriosis outbreak associated with ingestion of mud during a mountain bike race. Epidemiol Infect 2010;138:1695-1703.

Tri-County Health Department. Public Health Brief. Notifiable diseases 2009: A year in review. 2010. Available at: www .tchd.org/Archive.aspx?ADID=92, accessed February 19, 2016.

Varela NP, Dick P, Wilson J. Assessing the existing information on the efficacy of bovine vaccination against Escherichia coli O157:H7-A systematic review and meta-analysis. Zoonoses Public Health 2013;60:253-268.

Varma JK, Greene KD, Reller ME, DeLong SM, Trottier J, Nowicki SF, DiOrio M, Koch EM, Bannerman TL, York ST, Lambert-Fair MA, Wells JG, Mead PS. An outbreak of Escherichia coli $\mathrm{O} 157$ infection following exposure to a contaminated building. JAMA 2003;290:2709-2712.

Warshawsky B, Gutmanis I, Henry B, Dow J, Reffle J, Pollett G, Ahmed R, Aldom J, Alves D, Chagla A, Ciebin B, Kolbe F, Jamieson F, Rodgers F. Outbreak of Escherichia coli 0157:H7 related to animal contact at a petting zoo. Can J Infect Dis 2002;13:175-181.

Weese JS, McCarthy L, Mossop M, Martin H, Lefebvre S. Observation of practices at petting zoos and the potential impact on zoonotic disease transmission. Clin Infect Dis 2007;45:10-15.

Whatcom County Health Department. E. coli O157:H7 outbreak in Whatcom County, Washington. 2015. Available at: http:// wa-whatcomcounty.civicplus.com/CivicSend/ViewMessage/ Message?id=5760, accessed January 14, 2016.

Widmer AF. Replace hand washing with use of a waterless alcohol hand rub? Clin Infect Dis 2000;31:136-143.

Wilcock A, Pun M, Khanona J, Aung M. Consumer attitudes, knowledge and behaviour: A review of food safety issues. Trends Food Sci Technol 2004;15:56-66.

Williams LP, Newell KW. Salmonella excretion in joy-riding pigs. Am J Public Health 1970;60:926-929.

Winfield MD, Groisman EA. Role of nonhost environments in the lifestyles of Salmonella and Escherichia coli. Appl Environ Microbiol 2003;69:3687-3694.

Woodward DL, Khakhria R, Johnson WM. Human salmonellosis associated with exotic pets. J Clin Microbiol 1997;35: 2786-2790.

Address correspondence to: Tim McAllister, PhD Agriculture and Agri-Food Canada Lethbridge Research Centre 5403-1st Avenue South Lethbridge, AB T1J 4B1 Canada

E-mail: tim.mcallister@agr.gc.ca 